\title{
Women's Resistance to Patriarchal Culture in the Tarian Bumi novel by Oka Rusmini
}

\author{
Eko Hardinanto \\ Doctoral Program of Language and Literature Education, Universitas Negeri Surabaya \\ Lidah Wetan, Surabaya - Indonesia \\ Setya Yuwana Sudikan \\ Language and Literature Education Study Program, Postgraduate School, Universitas Negeri Surabaya \\ Lidah Wetan, Surabaya - Indonesia \\ Tengsoe Tjahjono \\ Language and Literature Education Study Program, Postgraduate School, Universitas Negeri Surabaya \\ Lidah Wetan, Surabaya - Indonesia
}

\begin{abstract}
This study aims to describe the struggle of women in the fight against patriarchal culture in the novel Tarian Bumi by Oka Rusmini. The Approach used in this research is descriptive qualitative. This research uses the theory of feminism as its analysis knife. The data source in this study is the novel Tarian Bumi by Oka Rusmini, published by PT. Gramedia Main Library. The steps taken in data collection are as follows: repeated reading as a whole of the novel to fully understand its contents, record words, sentences, or important data relating to the problem under study, record and collect relevant theories that are relevant relate to research, conduct research based on existing theories, and draw conclusions. The steps in data processing are as follows: data description, data classification, data analysis, data interpretation, and evaluation. Data analysis techniques used are: data processing and presentation, reading the entire data, coding data and interpreting data. The findings in this study are that women and men should obtain equality in their rights and obligations, so that women can get freedom like men. The female characters in the novel Tarian Bumi oppose their own customs and culture for the sake of the realization of equality of rights between men and women regardless of certain social groups. Triangualation is defined as a data collection technique that combines various data collection techniques and existing data sources (Sugiyono, 2012: 241). In addition to the validity of the data, researchers also used FGD (Focus Group Discussion) as a means of evaluating the accuracy of research.
\end{abstract}

Keywords: women, resistance, patriarchy, feminism

DOI: $10.7176 /$ RHSS/10-16-04

Publication date:August $31^{\text {st }} 2020$

\section{Introduction}

Oka Rusmini wrote the female leaders as victims of the adat system and touched on the ideologies that were behind the adat system that harmed women themselves. Oka Rusmini brings feminism in her novels. feminism is a set or combination of ideas that seek to study social life by positioning itself in the defense of women. That is, this theory is in favor of the subject imagined, namely the woman who will be defended, which is assumed to be oppressed or marginalized. In defending and attempting to change the condition of these women, the theories used are also very diverse and depend on how to view the issue. This diversity of theories is essentially a manifestation of the diversity of viewpoints on women.

Women's perspective views power as an important element in the construction of men's and women's relations. Also, this understanding is often difficult to apply to everyday life. Imagine, so far the power relations are considered to have a relationship with male and female relations to the extent that there can be appointed an unequal relationship (Santoso: 2011: 260). In everyday life inequality between men and women is seen in the division of labor. Men work outside the home while women work inside the house. In the novel Bumi Dances, women have been positioned as workers who support their families and sometimes even provide for themselves. An author is able to compose a fiction literary work including novels well and usually the theme adopted is taken from the life that was experienced by the author himself, the experience of others that the author saw and heard, or the imagination of the author. The theme is the basis of a story. Zulfahnur, et al (1996: 25) suggest that the term theme comes from the English theme, which means the idea which is the subject of a discussion or the main idea of an article. A theme is a central idea that underlies a story. The theme has three functions, namely as a guideline in making a story, the goal of producing the story, and binding the events of the story in a plot. According to Semi (1993: 42), the theme is a central idea that is the basis and purpose or mandate of the author to the reader. According to Nurgiyantoro $(2005: 68)$ the theme is the main idea or ideas that underlie literary works. The theme is the overall meaning supported by the story, and by itself it will be hidden behind the story 
that supports it.

Oka Rusmini is one of the women who helped enliven the Indonesian literary world. The themes raised include about feminism. One of the goals of adopting the theme of feminism is to equalize the position of women and men. During this patriarchal culture is still valid, so that the position of men is always considered higher than women. Walby (1989: 213-220) explains that patriarchy is a system of social structures, practices that place men in a dominant position, oppress, and exploit women.

In a patriarchal culture, women's values are weak and need protection from men not to make them strong while facing life's uncertainty. As a fiction writer, Oka Rusmini struggles to fight injustice through her works. The novels by Oka Rusmini are Oka Rusmini's efforts to bring the narratives of Balinese women who have been marginalized to return to the center and the writings conducted by Oka Rusmini are a political act of women. Wiyatmi (2010: 88) criticizes that Oka Rusmini's novels are included in social themes framed by the spirit of feminism in fighting patriarchal domination and violence against women. By following the framework of feminist discourse analysis, as stated by Reinharz (2005: 213), Indonesian novels, which in this case are considered as cultural artifacts are used as data sources to examine women individually or in groups, the relationship between women and men men, relationships between women, intersections between racial, gender, class, age, institutional, personal identity and views that shape women's lives.

Women authors and even feminists do not want patriarchal culture to continue, because it is the same as restraints on women. The theme of feminism is appropriately raised because women have personal freedom is political and do not want to be viewed in terms of sexism alone. Through the selected novel entitled Bumi Dances Oka Rusmini presents a reality of Bali which is remotely exotic, but actually harbors a deep wound for its inhabitants. This novel is interesting not only in terms of flowing, dense, and beautiful language style, but also from the story told in this novel, which tells the story of the struggle of Balinese women to achieve happiness and face the socio-cultural reality around them. The novel Tarian Bumi tries to describe the situation of Balinese people with various social problems and customary rules that must be obeyed. This novel explores the lives of Balinese women who incidentally are rarely found in existing literary works. The novel also tells of a rebellion against adat which was seen as a system of injustice by the female leaders in it. The role of characters is very important in a literary work (novel). Nurgiyantoro (2005: 176-194) distinguishes characters in several types of planting based on the angle from which the naming is done. Based on the point of view and review, a character can be categorized into several types of naming at once, namely: the main character and supplementary character, the protagonist and antagonist, simple and round figures, and static and dynamic figures.

The female leaders try to fight for their destiny by opposing adat. The opposition arises from various forms, one of which is a different caste marriage performed by Ida Ayu Telaga Pidada who comes from the Brahmin caste with Wayan Sasmitha who comes from a caste sudra. The novel Tarian Bumi by Oka Rusmini is a literary work that is not enough to enjoy, but needs to get a scientific response. Researchers feel interested to study it, especially to find out the lives of women who do not have to follow a patriarchal culture. Another consideration that researchers use is Oka Rusmini's creative process. His works received many awards, one of which was the Language Center of the Indonesian Ministry of National Education as Recipient of the 2003 Literary Writing Award for his novel Tarian Bumi. Based on this background, this study aims to describe the struggle of women leaders in fighting against patriarchal culture in the novel Tarian Bumi by Oka Rusmini.

Today many author women are popping up. This phenomenon is reviving the world of literature in Indonesia. The birth of literary works from their ideas brought a new atmosphere and enthusiasm in creating works without limits. Even the number of literatures that exist today, more than the number of writers. Their work is able to break various taboos in patriarchal culture, which fetter women. A patriarchal mindset is a mindset that considers women and men as human beings who have differences. Differences give rise to stereotypes about men and women. A man is required to have a brave nature, has a strong body, is not easy to cry while a woman must be a motherly, gentle, sensitive. But it is actually not absolutely inherent in women and men, as the times evolve, of course patterns of thinking also develop, as well as Indonesian women began to dare to break the shackles that had ensnared it. According to Bhasin and Khan (1995: 5) Feminism is an awareness of systematic injustice for women in various sectors of life, as well as conscious actions by women and men to change the situation. Feminism contains 3 important concepts, namely: a. Feminism is a belief that there is no sexuality, opposing the existence of a hierarchical position that causes superior and inferior positions between the sexes b. Feminism is a recognition that society has socio-cultural construction that affects women $\mathrm{c}$. Feminism sues differences that mix sex and gender so that women are made as a separate group in society. According to Kadarusman (2005: 27), feminism consists of several streams namely: Liberal Feminism, Radical Feminism, Marxist Feminism, and Socialist Feminism. Azis (2007: 93) adds another type of feminism, namely postmodernist feminism. Postmodernist feminists are those who are disappointed with the building of modernism, because women do not get the same position in the framework of public and social construction.

Basically the goal of feminism is to obtain equality between women and men. Feminism fights for the humanity of women, fights for women as fully independent human beings (women demanding their full rights as 
human beings). In principle, it is rooted in the position of women in a patriarchal (philosophical, political, economic, cultural, social) world and is oriented to changing patterns of power relations (Heroepoetri and Valentina, 2004: 7). Furthermore Helmanita (2018: 60) states that feminism is an ideology that fights for women's rights in education, politics and the social sphere.

From those various opinions, it can be concluded that feminism is the struggle of women in realizing equality of rights between men and women. Feminism is a concept that fights for women as fully independent human beings. So as to make women aware of their personal existence. Feminism is a women's movement that demands equal rights between men and women in the world of philosophy, politics, economics, social and culture.

\section{Method}

This study used descriptive qualitative method. The researcher describes systematically, factually, and accurately about the facts and causal relationships of the phenomenon under study. The data source in this study is the novel Tarian Bumi by Oka Rusmini, published by PT. Gramedia Main Library. The steps taken in collecting data are as follows: (1) Repeatedly reading the whole novel to understand its contents as a whole, (2) Record words, sentences, or important data relating to the problem under study, (3) Record and collect relevant theories related to research, (4) Conduct research based on existing theories, (5) Draw conclusions. The steps in data processing are as follows: data description, data classification, data analysis, data interpretation, and evaluation. Data analysis techniques used are: data processing and presentation, reading the entire data, coding data and interpreting data (Creswell, 2013: 276). In order to guarantee the validity of the data to be obtained in this study, the increase in validity will be done by using triangulation techniques. According to Moleong L. J (2002: 178) triangulation is a data validity checking technique that functions as a comparison or checking of data by utilizing something else in the data

\section{Data analysis}

Data analysis according to Gay (2006: 480) is an attempt by qualitative researchers to summarize the data that has been collected, accurately and reliably. Analysis of the data in this study focused on the discussion of the struggle of women in the fight against patriarchal culture in the novel Earth Dance by Oka Rusmini.

\subsection{The women' struggle to freely choose a life partner}

Women are often faced with quite complex problems that result from situations of men and women having unequal relations. This pattern of relations results in women experiencing a lot of injustices as discussed in the previous chapter. Women respond in various ways and attitudes. There are those who realize and grow critical awareness that continues to have the courage to oppose all forms of injustice, but many are not aware. This is caused by socialization of the community and family so that women themselves consider it as a nature. In the novel Tarian Bumi there are female leaders who dare to fight for their rights and oppose the patriarchal cultural system of society. The lake is a portrait of Balinese women's rebellion against oppressive cultural practices in its own way, living its life between the threshold of acceptance and disobedience, between surrender and freedom.

Through her novel, Oka Rusmini describes the figure of the struggle of women by looking at the other side of women, namely in terms of women's freedom to choose a life partner. The lake figure is also described by Oka as a woman who opposes the prevailing adat in Bali. Telagapun must accept the applicable customary law. He was eventually banished by his family and was no longer considered a Brahmin woman for marrying a Sudra man

(A.1.1) "Hari ini juga tiang akan menanggalkan nama Ida Ayu. Tiang akan jadi perempuan sudra yang utuh..." (Rusmini, 2017: 173).

("Today also the pole will take off Ida Ayu's name. The pole will become a complete sudra woman ... ") (Rusmini, 2017: 173).

The story of the struggle of Telaga and several other Balinese women in achieving happiness and facing the socio-cultural reality around her is what was raised by Oka Rusmini in her novel. Feminism is the struggle of women in realizing equality of rights between men and women. Bali is famous for its caste system, namely groups, social classes, and certain types due to birth. Caste here is very instrumental in life for example in choosing a life partner. The Balinese people consider that marriage is a very important thing. By their marriage, they have been considered as a full society and have obtained the rights and obligations of a community member and a group of relatives. Marriage can occur if they are from the same caste. The high-caste Balinese will take care of their daughters not to marry a man of lower caste because the marriage will bring shame to his family and will drop the prestige of the entire caste of the daughter.

It is also considered to bring bad luck to the people around him. As contained in the following data:

(A.1.2) "Berkali-kali tiang berkata, menikah dengan perempuan Ida Ayu pasti mendatangkan kesialan. Sekarang anakku mati! Wayan tidak pernah mau mengerti. Ini bukan cerita dongeng. Ini 
kebenaran. Kalau sudah begini jadinya aku harus bicara aoalagi!” Luh Gumbreg memukul dadanya. Menatap Telaga tidak senang.(Rusmini, 2017: 152)

("Many times the pole said, marrying a woman Ida Ayu would bring bad luck. Now my child is dead! Wayan never wants to understand. This is not a fairy tale. This is the truth. If it's like this, I have to talk more!" Luh Gumbreg hit his chest. Looking at the lake is not happy.) (Rusmini, 2017: 152)

The Balinese people highly uphold their cultural customs, they glorify noble values, for them by becoming a nobleman they will feel valued and respected.

(A.1.3) “...Tuniangmu adalah perempuan paling lugu. Baginya cinta itu sangat sakral. Dia juga sangat mengagungkan nilai-nilai bangsawan. Memang, dari luar dia terlihat sangat sopan pada orangorang diluar griya. Tetapi tuniangmu sangat tidak bisa menerima bila laki-laki griya menikah dengan perempuan biasa. Tuniangmu sangat kukuh. Kebangsawanan harus tetap dipertahankan sesuai dengan tradisi yang diwariskan orang-orang tua kita. Itu kata-kata yang selalu ia katakan pada sesama perempuan...(Rusmini, 2017: 19).

("... Your father is the most innocent woman. For him love is very sacred. He also greatly exalted the values of nobility. Indeed, from the outside he looks very polite to people outside the church. But your young man is very unacceptable if a griya man marries an ordinary woman. Your tuniang is very sturdy. Nobility must be maintained in accordance with the traditions inherited by our parents. Those are the words he always says to his fellow women ..) (Rusmini, 2017: 19).

Based on this description it can be concluded that socialist feminism is the story that Oka Rusmini raised in the novel. Socialist feminism understands the oppression of women through certain social groups or classes (Kadarusman, 2005: 27). One of them in choosing a life partner. Women should have the right to marry the man they love even though they have a different caste. But in Bali for women this is prohibited, if they want to marry men of different castes, women must be prepared to face the risks they will face. Here it appears that there are differences in the rights received by men and women who actually must be removed. Balinese women are entitled to equal rights for men. In this novel there are a number of women leaders who are considered to have rebelled against adat, namely the mother and child figures, Luh Sekar and Ida Ayu Telaga Pidada, and the Kenten figure, Sekar's playmate since childhood, who chose to be a lesbian and not marry a man. They fight for their dreams in achieving happiness and freedom to choose a partner even with different backgrounds. Luh Sekar is a woman from the lowest class (sudra) who strives very hard to marry a man from a noble caste (Brahmin).

(A.1.4) "Aku capek miskin, Kenten. Kau harus tahu itu. Tolonglah, carikan aku seorang Ida Bagus. Apapun syarat yang harus kubayar, aku siap!” (Rusmini, 2017: 17)

("I'm tired of being poor, Kenten. You must know that. Please, find me a good Ida. Whatever conditions I have to pay, I'm ready! ”) (Rusmini, 2017: 17)

These data indicate that Luh Sekar already has the soul of a socialist feminism with his desire to get a nobleman who he thinks will change his life for the better. Luh Sekar tried hard to realize his dream. Until finally he succeeded in marrying a blue blooded man, Ida Bagus Ngurah Pidada. Unfortunately Luh Sekar's marriage was not happy. His in-laws are vile and always look down on him.

(A.1.5) "Perempuan senior itu tak habis-habisnya memaki ibu. Kata-kata kasar dan sumpah serapah yang tidak jelas maknanya selalu meluncur teratur dari bibir tuanya yang selalu terlihat merah. Sebagai perempuan junior, ibu hanya bisa menunduk. Ibu tak pernah melawan nenek. padahal seringkali kata-kata nenek menghancurkan harga diri ibu sebagai perempuan.’(Rusmini, 2017: 13-14)

("The senior woman was incessantly cursing mother. Rude words and expletives that are not clear meanings always glide regularly from his old lips that always look red. As a junior woman, mother can only bow. Mother never fought grandma. whereas often the words of the grandmother destroy the pride of the mother as a woman.") (Rusmini, 2017: 13-14)

In addition, her noble husband turned out to be a drunkard and made love to just any woman, including Luh Sekar's half-sister. Luh Sekar paid a fortune in exchange for the comfort of his life by entering the world of the aristocracy. As it turned out, two of her twin sisters wanted to be made into the pets of Sekar's husband. The two women even shamelessly whispered the greatness of the man in bed.

(A.1.6) "Luar biasa laki-laki jero. Dia sekarang ada didalam!" "Sekar bergidik mendengar komentar Luh Kerti yang keluar membukakan pintu dalam kondisi sangat acak-acakan.” (Rusmini, 2017: 83).

("Extraordinary male Jero. He is now inside! " "Sekar shuddered when Luh Kerti's comment came out and opened the door in a very disheveled condition.") (Rusmini, 2017: 83).

The data shows the price to be paid dearly for Luh Sekar because he had exchanged his life's comfort by entering the world of the aristocracy. But Luh Sekar never gave up on fighting for his dream of becoming a 
complete nobleman. Luh Sekar's main concern is only with her child, Ida Ayu Telaga Pidada. He educates and always reminds him of the blue blood he bears and the various rules that Telaga must follow, including marrying a man who holds the title of Ida Bagus. The lake was not like his mother who upheld the value of the degree of nobility. For Telaga, Luh Sekar is a very strange woman. The woman glorified noble values. His mindset is difficult for Telaga to accept. According to the lake, the Brahmin caste is full of lies and hypocrisy. The lake finally fell in love with Wayan Sasmitha, a simple man, a painter from the Sudra caste. Then Telaga took off his royal robe, humbled himself, and killed the name of Ida Ayu who had once carried him. Telaga lives with Wayan's family in a simple house with a simple life, but Telaga gets the happiness she wants.

(A.1.7) "Cerita-cerita tentang Wayan terus mengalir. Telaga hanya bisa mendengarkan. Dia tidak ingin mengatakan apapun pada dua orang perempuan yang memeng suka membuat isu yang anehaneh itu. Bagi Telaga, cintanya pada Wayan yang dalam hanya ubtuk dirinya. Setiap kali kerinduan mengintip, Telaga hanya bisa menutup wajahnya dengan bantal. Menangis sepuasnya!" (Rusmini, 2017: 133)

("Stories about Wayan continue to flow. Lake can only listen. He did not want to say anything to the two women who wanted to make a strange issue. For Telaga, his deep love for Wayan is only for him. Every time a longing peeps, Telaga can only cover his face with a pillow. Cry to your heart's content!") (Rusmini, 2017: 133)

The data shows that Telaga really loves Wayan Sasmitha and continues to fight for his love even though many oppose it.

(A.1.8) "Hidup terus berjalan. Ketika keberanian itu muncul dan semakin matang, Telaga harus berhadapan dengan Luh Gumbreg, Ibu Wayan.” (Rusmini, 2017: 136)

("Life goes on. When that courage emerges and becomes more mature, Telaga must face Luh Gumbreg, Mrs. Wayan.") (Rusmini, 2017: 136)

(A.1.9) "Ternyata perempuan tua itu tidak berani menerimanya sebagai menantu. Seorang laki-laki sudra dilarang meminang perempuan brahmana. Akan sial jadinya bila Wayan mengambil Telaga sebagai istri. Perempuan sudra itu percaya pada mitos bahwa perempuan brahmana adalah surya, matahari yang menerangi gelap. Kalau matahari itu dicuri, bisakah dibayangkan akibatnya?" (Rusmini, 2017: 137)

("It turns out that the old woman did not dare to accept her as a daughter-in-law. A Shudra man is forbidden to propose to a Brahmin woman. It would be bad luck if Wayan took Telaga as his wife. The Shudras believe in the myth that Brahmin women are the sun, the sun that lights up the dark. If the sun is stolen, can you imagine the consequences?") (Rusmini, 2017: 137)

In the end Telaga continues to fight for its right to marry the man of her choice. He found his happiness in the midst of opposition between his family and Wayan's family. Lake is ready to bear the risk that will be received as a result of challenging customs.

The next figure who is also considered to be a rebellion against adat is the Kenten figure. Kenten is a Shudra woman from a simple family, her job is to lift firewood from the market. The manifestation of his rejection of adat is that he does not marry a man. Kenten doesn't want to be fooled by men. The patriarchal culture possessed by Bali caused men to be free to marry more than once, and Kenten did not want to be like that. That culture also always demeans women. Kenten does not want him not respected and respected by men.

(A.1.10) "Aku tidak akan kawin, Meme. Aku tidak ingin mereka bohongi. Aku benci seluruh laki-laki yang membicarakan perempuan dengan cara tidak terhormat!” (Rusmini, 2017: 34)

("I will not marry, Meme. I do not want them to lie. I hate all men who talk about women in a dishonorable way!") (Rusmini, 2017: 34)

\subsection{The women' struggle for the right to live in line with men}

In addition to fighting for their rights in choosing a life partner, Balinese women also fight for the right to live in line with men. In Bali, women work toil in order to meet the needs of their family life, while men only lazily sit in the stall from morning to afternoon just to chat. The description that women in Bali are hard-working women can be found in the following data:

(B.1.1) "Tidak. Aku tidak senang dengan gunjingan laki-laki yang duduk santai di kedai kopi setiap pagi. Sementara aku harus kerja keras, kaki mereka terangkat dikursi...." (Rusmini, 2017: 31).

("No. I'm not happy with the gossip of men sitting casually in the coffee shop every morning. While I have to work hard, their legs are lifted in a chair ...") (Rusmini, 2017: 31).

(B.1.2) "Alangkah mujurnya makhluk bernama laki-laki. Setiap pagi para perempuan berjualan di pasar, tubuh mereka dijilati matahari. Hitam dan berbau. Tubuh itu akan keriput..”(Rusmini, 2017: 35).

("How fortunate a creature is named a man is. Every morning the women sell at the market, their bodies are licked by the sun. Black and smelly. The body will wrinkle ...") (Rusmini, 
2017: 35)

The data illustrates that women always work while men only sit in coffee shops. Women who work hard but men who receive the results of their hard work are women. It is very unfair if men have more rights, especially in the marriage system that is free to marry any caste and more than once married, whereas women are only allowed to marry one caste. Even though women are hard working people but still they do not have special rights in adat, women are always underestimated. Balinese women in this novel are very obedient to adat, they do not dare to fight it but if seen on the other hand Balinese women if they want to go forward then they have to fight even though it will bear a high risk. Based on the description above it can be concluded that in a woman's life it is appropriate to obtain equality in life with men, so that women can get the freedom as what men get. Being a socialist feminism as in the novel Earth Dance, one way. Opposing their own customs and culture for the sake of the realization of equal rights between men and women regardless of certain social groups.

\section{Discussion}

The female character in the novel Tarian Bumi strives to fight against patriarchal culture. Various ways are taken to obtain rights like men. Based on data analysis, it was concluded that the author, Oka Rusmini, placed feminism in fighting for the fate of women in the novel Earth Dance.

\section{Conclusion}

The struggle of women leaders in fighting against patriarchal culture in the novel Tarian Bumi Karya Oka Rusmini, is often faced with quite complex problems caused by the situation of male relations with women who are not parallel. This pattern of relationships results in many women getting injustice. Women respond in various ways and attitudes. There are those who realize and grow critical awareness that continues to have the courage to oppose all forms of injustice, but many are not aware. It happened because of socialization of the community and family so that the women themselves considered it as a nature. Through her novel, Oka Rusmini describes the figure of the struggle of women by looking at the other side of women, namely in terms of women's freedom to choose a life partner. The story of the struggle of several Balinese women in achieving happiness and facing the socio-cultural reality around them was raised by Oka Rusmini in the novel Tarian Bumi. Balinese society is famous for its caste system, which is the grouping of social classes based on birth, this has an impact on the marriage system and various cultural regulations that actually fetter the Balinese women themselves. Basically all humans are born the same, they are born with the same rights. so it would be considered unfair if there were groupings of social classes in society such as those found in Bali. Being a Brahmin caste, the highest caste in Bali, is always considered honorable, while those born as the sudra caste, the lowest caste in Bali, must always respect and devote themselves to those born as royalty. In the novel Tarian Bumi there is a struggle for feminist ideology represented by the author through the figures of Telaga and Luh Sekar. These figures oppose adat especially in the marriage system in the hope that they will find happiness over their life choices, even though they have to bear heavy risks. In addition, the female characters in the novel also struggle to get the right to live in line with men.

\section{References}

Azis, Asmaeny. (2007). Feminisme Profetik. Yogyakarta: Kreasi

Bhasin dan Khan. (1995). Persoalan Pokok Mengenai Feminisme dan Relevansinya. Jakarta: Gramedia Pustaka Utama.

Creswell, J.W. (2013). Research Design (Pendekatan Kualitatif, Kuantitatif, dan Mixed) Edisi Revisi. Yogyakarta: Pustaka Pelajar.

Helmanita, Karlina. (2018). Critical Discourse Analysis on Ideology of Feminism in Nawāl Al-Sa'adāwi's Mudzakkirāt Thobībah. Journal of Education, Teaching and Learning. Volume 3 Number 1 March 2018. Page 60-71 p-ISSN: 2477-5924 e-ISSN: 2477-8478

Heroepoetri, A dan Valentina, R. (2004). Feminisme Vs Neoliberalisme. Jakarta: Debt Watch Indonesia

Kadarusman. (2005). Agama, Relasi dan Feminisme. Yogyakarta: Kreasi Wacana

Nurgiyantoro, Burhan. (2005). Teori Pengkajian Fiksi. Yogyakarta: Gajah Mada.

Reinharz, Shulamit. (2005). Metode-metode Feminis dalam Penelitian Sosial. Diterjemahkan dalam Bahasa Indonesia oleh Lisabona Rahman dan J. Bambang Agung. Jakarta: Woman Reseach Institute.

Rusmini, Oka. (2017). Tarian Bumi. Jakarta: PT Gramedia Pustaka Utama.

Santoso, Widjajanti M. (2011). Sosiologi Feminisme, Konstruksi Perempuan Dalam Industri Media. Yogyakarta: LKiS.

Semi, Atar. (1993). Anatomi Sastra Bandung : Angkasa Raya.

Sugiyono. (2012), Memahami Penelitan Kualitatif. Bandung: Alfabeta.

Walby, Silvia. (1989). Theorizing Patriarchy, in Sociology. Journal Vol 23 (2) hlm. 213- 231.

Wiyatmi. (2010). Citraan Perlawanan Simbolis terhadap Hegemoni Patriarki Melalui Pendidikan dan Peran 
Perempuan di Arena Publik dalam Novel Indonesia. Yogyakarta: UGM.

Zulfahnur dan Firdaus, Sayuti Kurnia, Yuniar Z. Adji.(1996). Teori Sastra. Jakarta: Pustaka Jaya. 